\title{
Aromatase Inhibitors Use for Endometriosis Patients
}

\author{
Shawky ZA Badawy ${ }^{1,2 *}$ and Jonathan D Franceschini ${ }^{1,2}$ \\ ${ }^{1}$ Department of Obstetrics and Gynecology, Division of Reproductive Endocrinology, Upstate Medical University, USA \\ ${ }^{2}$ Department of Clinical Pathology, Upstate Medical University, USA
}

*Corresponding author: Shawky ZA Badawy, Department of Obstetrics and Gynecology, Division of Reproductive Endocrinology,

Department of Clinical Pathology, Upstate Medical University, Syracuse, New York, USA

\begin{tabular}{lll}
\hline ARTICLE INFO & & ABSTRACT \\
\cline { 1 - 2 } $\begin{array}{l}\text { Received: 慧 August 14, } 2020 \\
\text { Published: }\end{array}$ & & $\begin{array}{l}\text { Citation: Shawky ZA Badawy, Jonathan D Franceschini. Aromatase Inhibitors Use for En- } \\
\text { dometriosis Patients. Biomed J Sci \& Tech Res 29(5)-2020. BJSTR. MS.ID.004854. }\end{array}$
\end{tabular}

\section{Introduction}

Endometriosis is a chronic inflammatory disease. The incidence of endometriosis is $10-20$ percent of women during reproductive years. It is a disease that affects many regions of the body including, pelvic cavity, abdominal cavity, chest, and subcutaneous tissues. The clinical picture depends on the organs affected by this disease process. Endometriosis depends on estrogen for its growth and survival. The main source of estrogen is the ovary. Therefore, the main line of treatment of these patients is to suppress the ovarian function, and thus decrease estrogen production that leads to inhibition of endometriosis growth. The other source of estrogen that stimulates the growth of endometriosis, is the endometriotic cells due to the presence of aromatase that converts testosterone to estradiol and androstenedione to estrone $[1,2]$. This explains the recurrence of endometriosis following removal of the ovaries, and also in menopausal women. Aromatase is present also in subcutaneous fat, skin fibroblasts, placental syncytiotrophoblast, osteoblasts and the brain $[3,4]$. Aromatase is stimulated by prostaglandin E2 in endometriotic stromal cells.

\section{Aromatase Inhibitors for Treatment of Endometriosis}

According to the pathogenesis of endometriosis and the various sources of estrogen for the growth of the disease, treatment must be focused on the suppression of estrogen sources. Therefore, the treatment of a patient with endometriosis during the reproductive years must include 2 agents:

a. Agent to suppress hypothalamic pituitary axis and this includes oral progestogens or GnRH agonist, and b. Aromatase inhibitor as Letrozole or Anastrozole to suppress the aromatase produced by endometriosis cells and peripheral tissues as stated.

A meta-analysis of eight trials included 137 women showed that combination of aromatase inhibitors with progestins, oral contraceptives, or GnRh agonists, relieved the pain, reduced the size of the lesions, and improved the quality of life. The European Society of Reproduction and Embryology recommends the use of aromatase inhibitor with oral contraceptives or GnRH agonist for endometriosis patients with pain from rectovaginal endometriosis, refractory to other medical or surgical treatment [5]. In our laboratory, we have shown that aromatase inhibitor significantly inhibited the growth of endometriosis cells in culture [6].

\section{Postmenopausal Endometriosis}

History of endometriosis dates back to 1690 when it was first described by Daniel Cristianus. The first report of postmenopausal endometriosis was 250 years later. The first case reported was by Edgar Haydon in 1942; in a 78-year-old woman. In 1960, Kempers et al reported a series of 136 women with postmenopausal endometriosis. In 1980, Punnonen et al reported 11 cases of postmenopausal ovarian endometriosis [7]. The data in the literature reports an incidence of $2-5 \%$ of endometriosis in postmenopausal women between ages of 55-95 years old. Sources of estrogen could be from hormonal therapy. It also could be due to aromatase that is present in various tissues. In postmenopausal endometriosis, the treatment will focus on the use of aromatase 
inhibitor to suppress estrogen from all peripheral sources [8]. All this data from both clinical studies, and laboratory studies, suggest that the use of aromatase inhibitors for endometriosis treatment is very effective in alleviating the symptoms and decreasing the lesions. Also, aromatase inhibitors are excellent line of treatment for menopausal endometriosis [9].

\section{References}

1. Velasco I, Rusda J, Acien P (2006) Aromatase expression in endometriotic tissues and cell cultures of patients with endometriosis. Molecular Human Reproduction 12(6): 377-381.

2. Acien P, Velasco I, Gutierrez M, Martinez Beltran M (2007) Aromatase expression in endometriotic tissues and its relationship to clinical and analytical findings. Fertil Steril 88(1): 32-38.

3. Sasson IE, Taylor HS (2009) Aromatase inhibitor for treatment of recurrence after laparoscopic treatment of endometriosis. Fertil Steril 92(3): 1170.e1-1170.e4.

ISSN: 2574-1241

DOI: 10.26717/BJSTR.2020.29.004854

Shawky ZA Badawy. Biomed J Sci \& Tech Res

(C) This work is licensed under Creative

Submission Link: https://biomedres.us/submit-manuscript.php
4. Snyder BM, Beets JW, Lessey BA, Horton SRW, Abrams GA (2018) Postmenopausal Deep Infiltrating Endometriosis of the Colon: Rare Location and Novel Medical Therapy. Case reports in gastrointestinal medicine.

5. Dunselman GA, Vermeulon N, Becker C, C Calhaz Jorge, T D'Hooghe, et al. (2014) ESHRE guidelines: management of women with endometriosis. Hum Reprod 29(3): 400-412.

6. Badawy SZA, Brown S, Kaufman L, Wojtowyca MA (2015) Aromatase inhibitor (Anastrozole) affects growth of endometrioma cells in culture. European J Obstet Gynecol and Reprod Biol 188: 45-50.

7. Punnonon R, Klemi PJ, Nikkanen V (1980) Postmenopausal endometriosis. Eur J Obstet Gynecol Reprod Biol 11(3): 195-200.

8. Pdyzos NP, Faterni HM, Zavoset, Grigoris Grimbizis, Dimitra Kyrou, et al. (2012) Aromatase inhibitors in postmenopausal endometriosis. Reprod Biol and endocrine.

9. Mousa NA, Bedaiwy MA, Casper RF (2007) Aromatase inhibitors in the treatment of severe endometriosis. Obstet Gynecol 109(6): 1421-1423.

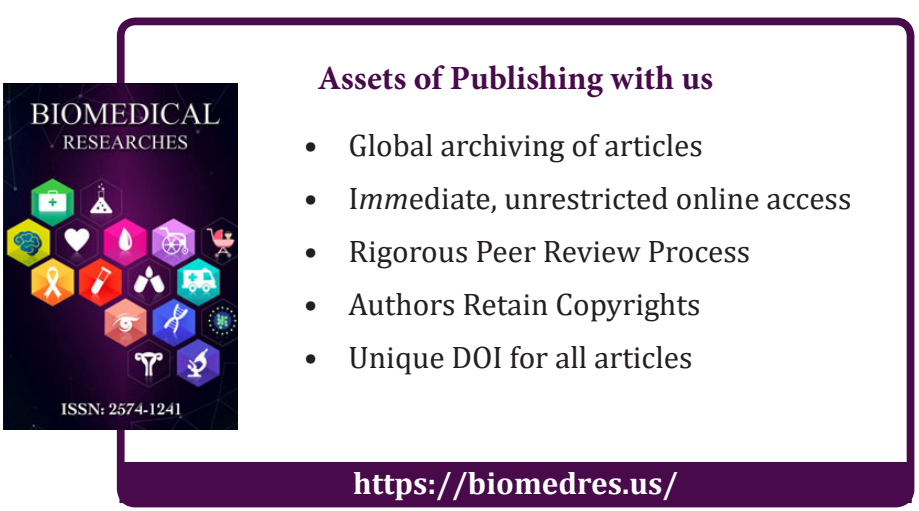

